PENGARUH KARAKTERISTIK DEMOGRAFIS, KNOWLEDGE DAN INTERAKSI

SOSIAL DI TEMPAT KERJA TERHADAP PRODUKTIVITAS KARYAWAN LANJUT USIA

DI PT SEMEN PADANG

TESIS

Disusun dan Diajukan Untuk Memenuhi Sebagian Persyaratan Mencapai Derajat Sarjana Strata-2 Program Studi Magister Manajemen Fakultas Ekonomi Universitas Andalas

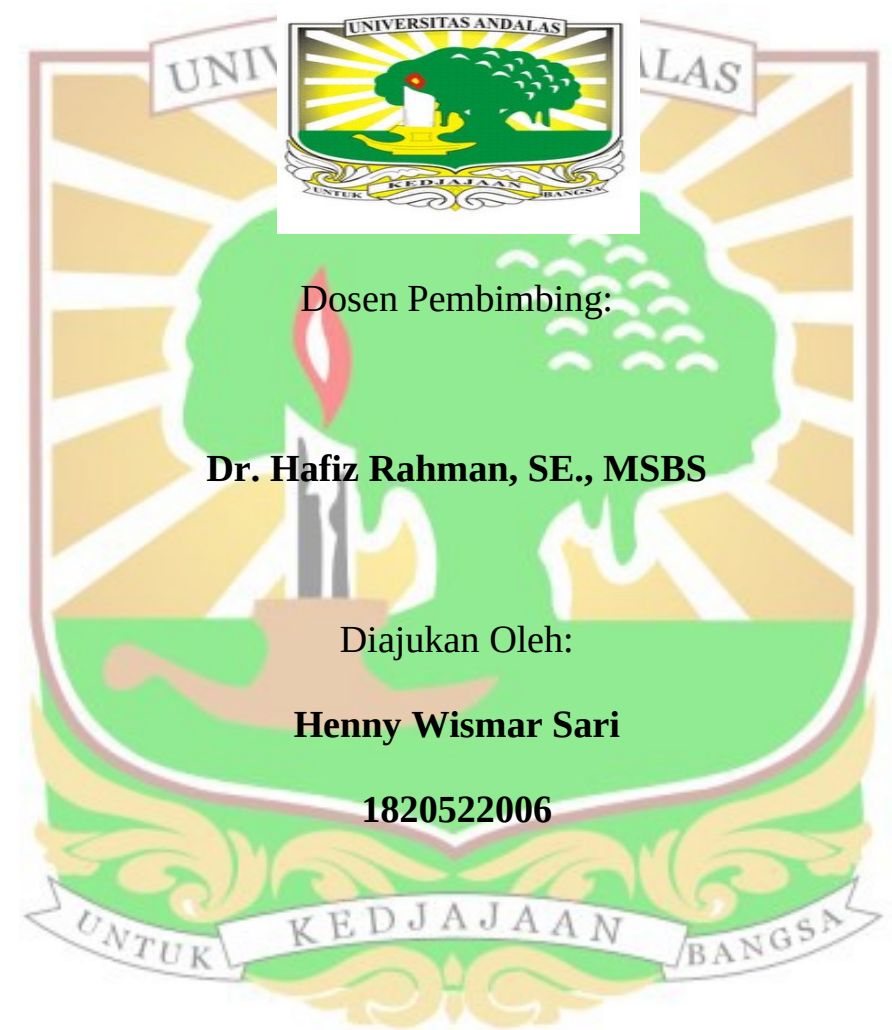

PROGRAM STUDI MAGISTER MANAJEMEN

FAKULTAS EKONOMI

UNIVERSITAS ANDALAS

2020 


\title{
PENGARUH KARAKTERISTIK DEMOGRAFIS, KNOWLEDGE DAN INTERAKSI SOSIAL DI TEMPAT KERJA TERHADAP PRODUKTIVITAS KARYAWAN LANJUT USIA DI PT SEMEN PADANG
}

\begin{abstract}
ABSTRAK
Tujuan utama penelitian ini adalah untuk mengetahui pengaruh karakteristik demografis terhadap produktivitas karyawan lanjut usia, pengaruh knowledge terhadap produktivitas karyawan lanjut usia dan pengaruhinteraksi sosial terhadap produktivitas.

Hasil penelitian menunjukkan bahwa karakteristik demografis berpengaruh positif terhadap produktivitas karyawan lanjut usia. Terdapat pengaruh positif pengetahuan terhadap produktivitas karyawan dan menunjukkan bahwa interaksi sosial di tempat kerja berpengaruh positif terhadap produktivitas karyawan lanjut usia.
\end{abstract}

Kata Kunci : karakteristik demografis, knowledge, interaksi sosial, produktivitas

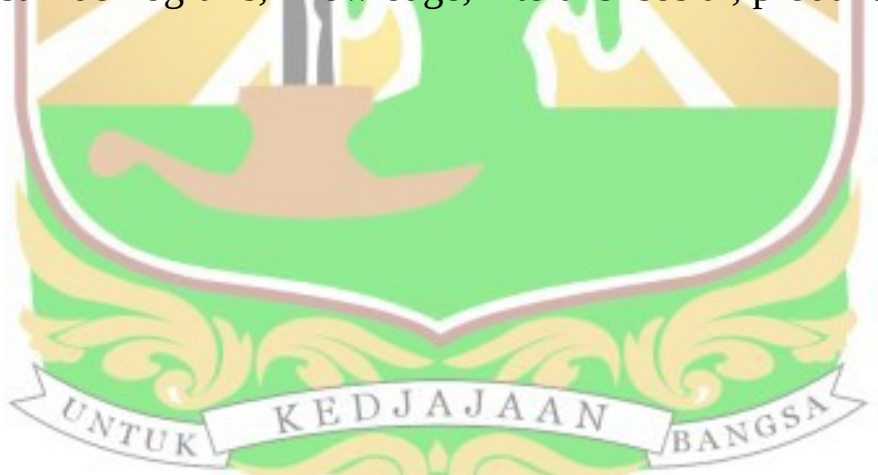




\title{
THE INFLUENCE OF DEMOGRAPHIC CHARACTERISTICS, KNOWLEDGE AND SOCIAL INTERACTION AT WORK ON THE PRODUCTIVITY OF ELDERLY EMPLOYEES AT PT SEMEN PADANG
}

\begin{abstract}
The main objective of this study was to determine the effect of demographic characteristics on the productivity of elderly employees, the influence of knowledge on the productivity of elderly employees and the effect of social interaction on productivity.

The results showed that demographic characteristics have a positive effect on the productivity of elderly employees. There is a positive influence of knowledge on employee productivity and it shows that social interaction at work has a positive effect on the productivity of elderly employees.
\end{abstract}

Keywords : Demographic characteristics, knowledge, social interaction, productivity.

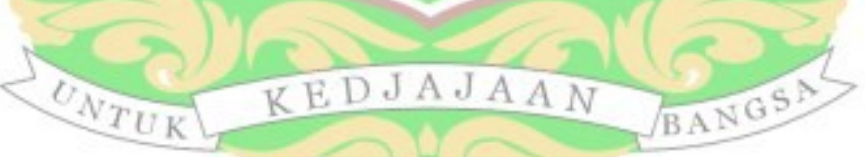

